\title{
Gospin plač u Klimantovićevu zborniku I. ${ }^{1}$
}

Čovjeku urođen osjećaj za dramatsko u kultu nalazi plodno tlo za izražavanje i razvoj. U srednjem vijeku znatan prostor zauzimaju pasionske teme. Jedna je od njih Gospin plač, dan-danas vrlo omiljen pjesnički oblik hrvatske pasionske baštine, kao izričaj Gospine duševne i tjelesne boli nad nevino osuđenim Sinom. Danas je on u svojim brojnim hrvatskim inačicama uglavnom dobro proučen. Njegovo pak proučavanje u Klimantovićevu zborniku može donijeti nova saznanja o toj glasovitoj pasionskoj pjesmi, a možda još više o samome Klimantovićevu zborniku.

Poznata je činjenica da čovjeku urođen osjećaj za dramatsko u kultu nalazi plodno tlo za izražavanje i razvoj. U srednjem vijeku znatan prostor u dramatizaciji zauzimaju pasionske teme. U hrvatskoj pasionskoj baštini vrlo je popularan i omiljen bio, a u novije doba opet postaje, Gospin plač.

Plačevi su dijaloške pjesme u kojima se opjevava pasionska tema Marijine supatnje. Bili su sastavni dio pučke pobožnosti koja je pratila liturgiju i njome se nadahnjivala. Plačevi su se pjevali u okviru pobožnosti Svetoga tjedna. Tradicija pjevanja u nekim se našim krajevima zadržala do danas, a negdje se ona oživljuje ili uvodi.

Gospin plač, u svojim mnogim hrvatskim inačicama, u starijoj je hrvatskoj književnosti uglavnom dobro proučen. Danas se općenito drži da je taj dio naše pasionske baštine samosvojan, da je nastao bez izravne veze s analognim ostvarenjima istoga žanra drugih europskih naroda. Glede proučavanja Gospina plača u Klimantovićevu zborniku, moglo bi se očekivati novih saznanja i o toj glasovitoj pasionskoj pjesmi, o samome Klimantoviću i ovom njegovu zborniku.

O fra Šimunu i njegovu zborniku bit će nešto više govora, a treći element, Hrvatsku provinciju franjevaca trećoredaca glagoljaša, ovdje ću samo spomenuti. Ona daje kontekst cijelom simpoziju - bit će dotaknuta, izravnije ili manje izravno, s različitih gledišta, pa ćemo ovdje spomenuti samo jednu rečenicu: Hrvatska provincija franjevaca trećoredaca od svoga postanka u Hrvatskoj upotrebljava glagoljicu i hrvatski crkvenoslavenski jezik kao liturgijski jezik.

Tekst izrečen na međunarodnom znanstvenom simpoziju Trećoredska glagoljaška tradicija u europskom kontekstu - Tertiary Glagolitic Tradition in European Context, Zagreb (Hrvatsko katoličko sveučilište), 28. IX. 2013. 
Fra Šimun Klimantović, prepisivač zbornika o kojem je riječ, vrlo je zanimljiv lik. Fra Petar Runje svojim je arhivskim istraživanjem potvrdio ili proširio mnoga saznanja o njemu. Fra Šimun rođen je oko 1460. u selu Lukoranu na otoku Ugljanu, kako to sam kaže u jednom svom kodeksu. Na jednoj latinskoj knjizi koju je prevodio stoji: „Ê fratar f'ra Šimunь, sinь Juriê K'lemenovića z Lukorana s'pridь Zad'ra, t'rêtoga rêda b(la)ž(e)noga F'ran'čiška, z'vanihь ods pokorê, vb provin'cii Dalmacie, nedos'toini fr(a)trb, ni pisac ni podь pis'сеть ріsacь“. Kako se vidi iz toga i iz mnogih drugih zapisa, Klimantović o svojem radu sudi vrlo skromno. Ipak, prema njegovu radu zaključujemo da je bio učen i cijenjen redovnik te da je u Provinciji obnašao različite službe. Milčetić kaže kako je on najmarljiviji književnik među franjevcima svoga vremena.

Fra Šimun je za potrebe svoje redovničke zajednice napisao tri zbornika. Najvažniji je i najcjelovitiji upravo ovaj o kojem će ovdje biti riječi: Prvi Klimantovićev zbornik, koji se nalazi u Arhivu Provincije franjevaca trećoredaca na Ksaveru, sadrži značajan obrednik, pa se po tome katkad i naziva Klimantovićevim obrednikom. Zbornik je pisan od 1501. do 1512.

Kukuljević, kao i Fancev pisca zbornika fra Šimuna pogrešno nazivaju malobraćaninom. Da se pogreške velikih autoriteta teško ispravljaju pokazuje i inače dobro zamišljen zbornik Hrvatsko srednjovjekovno pjesništvo. Pjesme, plačevi i prikazanja na starohrvatskom jeziku (Zagreb 2010.), gdje je fra Šimun također nazvan malobraćaninom te se navodi da je zbornik prepisao za potrebe samostana Male braće u Zadru (str. 355). Istina je da je zbornik bio u Zadru, ali ne u samostanu manje braće, nego u trećoredskom samostanu sv. Mihovila, odakle je $\mathrm{u}$ vrijeme talijanske okupacije prenesen u Zagreb, na sv. Ksaver.

O prvom se Klimanovićevu zborniku dosta pisalo; on se, u cijelosti ili u dijelovima, prepisivao i objavljivao, a nedavno je o njemu napisana i jedna doktorska disertacija (Katarina Lozić Knezović).

Sadržaj zbornika mogao bi se podijeliti na tri dijela:

a) ljetopisni dio

b) molitveno-obredni dio

c) poučni dio.

Ljetopisni je dio najkraći i nalazi se na različitim mjestima. On je zanimljiv, ali ga ovdje posve ostavljam sa strane. Druga dva dijela teško je precizno razgraničiti, pa ću ih nabrojiti po redu, kao jednu cjelinu:

Blagoslov stola 1. 2r-9r

Katekizamske formule, $1.9 \mathrm{v}-12 \mathrm{r}$

Pravilo III. reda od pokore, $1.12 \mathrm{r}-23 \mathrm{v}$ 
Oporuka sv. Franje, 1. 23v-28r

Obred redovničkog oblačenja, 1. 28r-32r

Obred redovničkog zavjetovanja, 1. 32r-33r

Kostacioni, 1. 33r-43v

Gospin plač, 1. 44r-69r

Mrtvačke pjesme, 1. 69r-82r

Pokornički psalmi, 1. 83r-93v

Služba za mrtve, 1. 94r-116r

Davanje popudbine bolesniku, 1. 116r-121r

Preporuka duše, 1. 121r-126r

Obred pogreba, 1.126r-145v

Obred krštenja, $1.145 \mathrm{v}-160 \mathrm{v}$

Misa za mrtve, 1. 161r-169r

Opća ispovijed, 1. 169r-202v

Različiti blagoslovi, 1. 202v-215r

O deset moći sv. mise, $1.215 \mathrm{v}-218 \mathrm{v}$

Različita odrješenja, $1.218 \mathrm{v}-225 \mathrm{v}$

Bula Aleksandra VI. Klimantoviću, 1. 225v-227v.

Prema obredima koje je Klimantović odabrao, vidi se da to nije službeni, nego priručni obrednik. Pravilo III. reda prijevod je pravila za Treći red koje je odobrio papa Nikola IV. Isto je tako i oporuka sv. Franje prijevod s latinskoga. Spovid općena sadrži upute ispovjednicima i ispit savjesti. Ima mnogo sličnosti s tiskanom knjižicom Spovid općena (Senj 1496.), ali je tekst mnogo kraći i pokazuje više starine nego tekst tiskane knjižice.

Zanimljiv je tekst pod naslovom Kostacioni bratie pokor 'nih' iz 1492. To nisu konstitucije $u$ današnjem smislu te bi bilo zanimljivo proučiti taj tekst pod tim vidom, naime, smjestiti ga u niz dokumenata te vrste. Zbornik završava ljetopisnim dijelom, a njegova posljednja bilješka govori o knjižici i njezinu piscu: „Te k'nižice napisah' na s'lvu Bžiju i b'žene Gospoe ê f'ratar' f'ra Šimun' sn' Juriê Klemenovića z' Lukora(na) tretoga reda za utišeniê moe brat'jice i dovrših' e v' Zag'lavi pri stom' Mihovili .i.v. (23.) per'vara .č.f.b.ï. (1512.).“

Za franjevce trećorece značajan je već spomenuti tekst pod naslovom Kostacioni (op. a. - drugo slovo nejasno, barem na filmu: os ili us), a za opće značenje upravo tekst koji je tema ovog izlaganja: Gospin plač. U hrvatskoj srednjovjekovnoj književnoj baštini Gospin plač poznat je u više inačica, a dvije su osnove redakcije. Tekst u Prvom Klimanovićevu zborniku pripada starijoj redakciji, naslanja se zapravo na najstariji glagoljički prijepis iz 15. stoljeća.

Plačevi su se redovito pisali u parno rimovanim osmercima, a prozne didaskalije, ponegdje vrlo iscrpne, olakšavale su dramsko izvođenje. Gospin plač Prvog 
Klimanovićeva zbornika spada među najbolje sačuvane tekstove plača. Cijeli zbornik, pa tako i njegov Gospin plač, ispisan je lijepim i čitkim poluustavom, jedino je na pojedinim mjestima lošije čitljiv.

Plač u Prvom Klimanovićevu zborniku počinje riječima Plač Gospoje i podnaslovom Počenjet plač blažene Dive Marije po Ivani Vanjelisti. Pisan je na 26 listova, a ima 1120 stihova te spada među duže tekstove. Jezik je, kao i u svim drugim plačevima toga doba, čakavski. U plaču tog zbornika, u usporedbi s drugim plačevima, ima ponešto jezičnih vlastitosti, ali to je već tema za druge radove. Tekst se prepisivao i više puta objavljivao, posljednji put 2010. u spomenutom zborniku u svojevrsnom kritičkom izdanju.

Kad se radi o ovako dugačkom tekstu, ostaje pitanje koje se obično postavlja na početku: U kojem bi smjeru, uvažavajući dosada postignuto, trebalo krenuti i koji bi se rezultati mogli očekivati? Mislim da sam došao do nekih naslućivanja, a do nečeg značajno novoga u ovoj se vrsti posla može doći ili slučajno ili nakon dugotrajnog i mukotrpnog istraživanja.

\section{Bibliografija}

Hrvatsko srednjovjekovno pjesništvo. Pjesme, plačevi i prikazanja na starohrvatskom jeziku. 2010. Tekstove kritički priredili i osvrte na tekstove sastavili Amir Kapetanović, Dragica Malić, Kristina Štrkalj Despot, autor koncepcije i uvodne studije Amir Kapetanović. Zagreb: Institut za hrvatski jezik i jezikoslovlje.

LOZIĆ KNEZOVIĆ, Katarina. 2010. Leksik Klimantovićeva zbornika iz 1512. g. Doktorska disertacija. Zagreb: Filozofski fakultet Sveučilišta u Zagrebu.

RUNJE, Petar. 2001. Fra Šimun Klimantović i Konstitucije 1492. U Iskoni bê slovo. Zbornik radova o glagoljici i glagoljašima zadarskog kraja i crkvi Svetog Ivana Krstitelja. Ur. Antun Badurina, 183-193 [Novaja i vethaja 7]. Zagreb: Provincijalat franjevaca trećoredaca, Kršćanska sadašnjost.

RUNJE, Petar. 2012. Prema izvorima II. Rasprave i članci o hrvatskim franjevcima trećoredcima glagoljašima. Ur. Tomislav Galović [Novaja i vethaja 9; Krčki zbornik 68, Posebno izdanje 61]. Krk-Zagreb: Povijesno društvo otoka Krka, Provincijalat franjevaca trećoredaca.

Spovid općena (latinička transkripcija glagoljskog teksta tiskanog god. 1496. u Senju). 1979 (i pretisak 27. listopada 1978). Ur. Anica Nazor i Branko Fučić. Senj: Senjsko muzejsko društvo. 


\section{Madonna's Cry in the Collectaneum of Klimantović I}

Man's innate dramatic sense finds in worship fertile ground for its expression and development. The Passion motives are widely spread in the Middle Ages. The composition Madonna's cry has been very popular in the Croatian Passion tradition and in recent years it has been regaining its historical popularity. This poetic work is today mainly well researched and that goes for the many Croatian versions too. However, its study in the Collectaneum of Klimantović may provide new insights both into that famous Passion poem and, possibly even more, into the Collectaneum itself.

Keywords: Madonna's Cry, Collectaneum of Klimantović I

Ključne riječi: Gospin plač, Klimantovićev zbornik I.

Petar Bašić

Katolički bogoslovni fakultet Sveučilišta u Zagrebu HR-10000 Zagreb, Vlaška ulica 38

pbasic@inet.hr 


\section{FILOZOFSKI FAKULTET SVEUČILIŠTA U ZAGREBU \\ ZAVOD ZA HRVATSKU POVIJEST \\ INSTITUTE OF CROATIAN HISTORY \\ INSTITUT FÜR KROATISCHE GESCHICHTE}
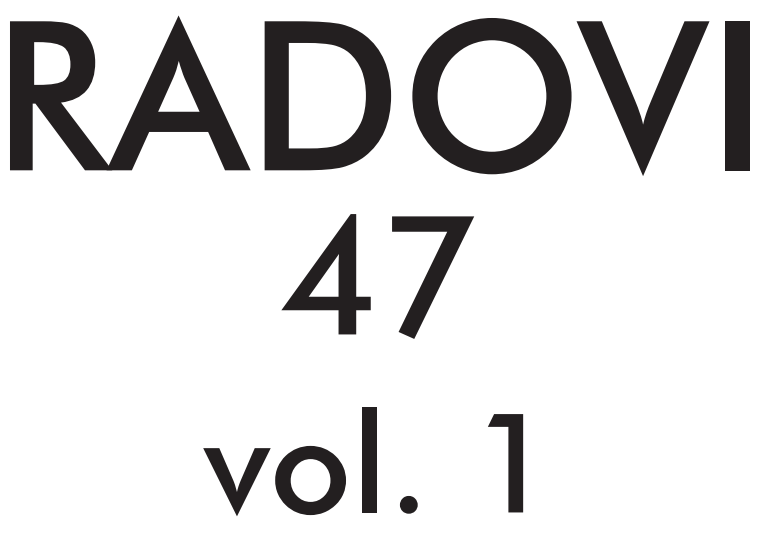

ZAVOD ZA HRVATSKU POVIJEST

FILOZOFSKOGA FAKULTETA SVEUČILIŠTA U ZAGREBU

\section{PF press \\ ZAGREB 2015.}




\title{
RADOVI ZAVODA ZA HRVATSKU POVIJEST FILOZOFSKOGA FAKULTETA SVEUČILIŠTA U ZAGREBU
}

\author{
Knjiga 47, vol. 1
}

\author{
Izdavač / Publisher \\ Zavod za hrvatsku povijest \\ Filozofskoga fakulteta Sveučilišta u Zagrebu \\ FF-press \\ Za izdavača / For Publisher \\ Vlatko Previšić \\ Glavni urednik / Editor-in-Chief \\ Hrvoje Gračanin \\ Izvršna urednica / Executive Editor \\ Inga Vilogorac Brčić \\ Uredništvo / Editorial Board
}

Bruna Kuntić-Makvić (stara povijest/ancient history), Zrinka Nikolić Jakus (srednji vijek/ medieval history), Hrvoje Petrić (rani novi vijek/early modern history), Željko Holjevac (moderna povijest/modern history), Tvrtko Jakovina (suvremena povijest/contemporary history),

Silvija Pisk (mikrohistorija i zavičajna povijest/microhistory and local history),

Zrinka Blažević (teorija i metodologija povijesti/theory and methodology of history)

Međunarodno uredničko vijeće / International Editorial Council

Denis Alimov (Sankt Peterburg), Živko Andrijašević (Nikšić), Csaba Békés (Budapest), Rajko Bratož (Ljubljana), Snježana Buzov (Columbus, Ohio), Svetlozar Eldarov (Sofija), Toni Filiposki (Skopje), Aleksandar Fotić (Beograd), Vladan Gavrilović (Novi Sad), Alojz Ivanišević (Wien),

Egidio Ivetić (Padova), Husnija Kamberović (Sarajevo), Karl Kaser (Graz),

Irina Ognyanova (Sofija), Géza Pálffy (Budapest), Ioan-Aurel Pop (Cluj),

Nade Proeva (Skopje), Alexios Savvides (Kalamata), Vlada Stanković (Beograd), Ludwig Steindorff (Kiel), Peter Štih (Ljubljana)

Izvršna urednica za tuzemnu i inozemnu razmjenu / Executive Editor for Publications Exchange Kristina Milković

Tajnik uredništva / Editorial Board Assistant

Dejan Zadro

Adresa uredništva/Editorial Board address

Zavod za hrvatsku povijest, Filozofski fakultet Zagreb, Ivana Lučića 3, HR-10 000, Zagreb

Tel. ++385 (0)1 6120 150, 6120 158, faks ++385 (0)1 6156879

Časopis izlazi jedanput godišnje / The Journal is published once a year

Časopis je u digitalnom obliku dostupan na / The Journal in digital form is accessible at Portal znanstvenih časopisa Republike Hrvatske „Hrčak“ http://hrcak.srce.hr/radovi-zhp

Financijska potpora za tisak časopisa / The Journal is published with the support by

Ministarstvo znanosti, obrazovanja i športa Republike Hrvatske

Časopis je indeksiran u sljedećim bazama / The Journal is indexed in the following databases:

Directory of Open Access Journals, EBSCO, SCOPUS, ERIH PLUS 
Naslovna stranica

Iva Mandić

Grafičko oblikovanje i računalni slog

Marko Maraković

Lektura

Samanta Paronić

Tisak

Web2tisak, Zagreb

Naklada

250 primjeraka

Časopis je u digitalnom obliku dostupan na Portalu znanstvenih časopisa Republike Hrvatske ,Hrčak“ http://hrcak.srce.hr/radovi-zhp

The Journal is accessible in digital form at the Hrcak - Portal of scientific journals of Croatia http://hrcak.srce.hr/radovi-zhp 


\section{RADOVI 47}

\section{vol. 1}

ZaVoda za hrVAtSku poviJest FILOZOFskoga fakulteta SVeuČILIŠTA u Zagrebu 


\title{
Tematski blok / Themed issue
}

\section{TREĆOREDSKA GLAGOLJAŠKA TRADICIJA U EUROPSKOM KONTEKSTU TERTIARY GLAGOLITIC TRADITION IN EUROPEAN CONTEXT}

\author{
Radovi međunarodnoga znanstvenog skupa \\ održanoga 27. i 28. IX. 2013. na Hrvatskom katoličkom sveučilištu u Zagrebu \\ u organizaciji \\ Provincije franjevaca trećoredaca glagoljaša u Zagrebu, Hrvatskoga katoličkog \\ sveučilišta u Zagrebu, Filozofskoga fakulteta Sveučilišta u Zagrebu - Odsjek za \\ povijest, Filozofskoga fakulteta Sveučilišta u Splitu - Odsjek za povijest, Instituta \\ za povijest umjetnosti u Zagrebu i Staroslavenskoga instituta u Zagrebu \\ Proceedings of the International Scientific Conference \\ held on 27th and 28th September 2013 at the Catholic University of Croatia in Zagreb \\ and organized by \\ the Province of the Glagolitic Friars of the Third Order Regular, Catholic University \\ of Croatia in Zagreb, Faculty of Humanities and Social Sciences of the University \\ of Zagreb - Department of History, Faculty of Humanities and Social Sciences of \\ the University of Split - Department of History, Institute of Art History, \\ and Old Church Slavonic Institute
}

Gosti urednici / Guest editors

\author{
Ivan BOTICA \\ Tomislav GALOVIĆ \\ Kristijan KUHAR
}

